Article

\title{
Wood Decay Fungi Restore Essential Calcium to Acidic Soils in Northern New England
}

\author{
Walter C. Shortle * and Kevin T. Smith \\ USDA Forest Service, Northern Research Station, 271 Mast Road, Durham, NH 03824, USA; \\ E-Mail: ktsmith@fs.fed.us \\ * Author to whom correspondence should be addressed; E-Mail: wshortle@fs.fed.us; \\ Tel.: +1-603-868-7620; Fax: +1-603-868-7604.
}

Academic Editor: Douglas L. Godbold

Received: 12 June 2015 / Accepted: 23 July 2015 / Published: 29 July 2015

\begin{abstract}
The depletion of root-available calcium in northern forests soils exposed to decades of increased acid deposition adversely affects forest health and productivity. Laboratory studies indicated the potential of wood-decay fungi to restore lost calcium to the rooting zone of trees. This study reports changes in concentrations of $\mathrm{Ca}, \mathrm{Mg}$, and $\mathrm{K}$ during decay of sapwood of spruce, maple, hemlock, and birch at two locations in northern New England, USA. Concentrations of exchangeable $\mathrm{Ca}, \mathrm{Mg}$, and $\mathrm{Al}$ in decayed wood residues after 10 and 12 years of ground contact were also compared. Significant loss of mass indicated by decreasing wood density occurred after two to eight years in conifers and after only two years in hardwoods. A significant gain in wood $\mathrm{K}$ was observed at two years, but the gain was not sustained. A significant gain in $\mathrm{Ca}$ concentration occurred by six years and that gain was sustained for 12 years. Concentrations of $\mathrm{Mg}$ varied. No significant difference in exchangeable $\mathrm{Ca}$ concentration was observed between decayed wood residue of spruce and maple and the forest floor. However, decayed wood residue had a much lower molar $\mathrm{Al} / \mathrm{Ca}$ ratio, a conditional characteristic of sites with high root-available $\mathrm{Ca}$.
\end{abstract}

Keywords: wood decay; forest biogeochemistry; base cation cycling 


\section{Introduction}

Ecto-mycorrhizal fungi (EMF) and wood-decay fungi (WDF) in forest soils have major effects on biogeochemical cycling of carbon (C) and essential mineral elements in temperate and boreal forest ecosystems [1]. The role of EMF and WDF in making the growth-limiting nutrients nitrogen (N) and phosphorus (P) is well known (e.g., [2]). Nitrogen and $\mathrm{P}$ along with potassium (K) and magnesium $(\mathrm{Mg})$ are essential for $\mathrm{C}$ fixation in photosynthesis and for the functioning of the symplast, the interconnected network of live cell contents in the outer wood and inner bark from root tip to foliage.

As part of this special journal issue on ECM fungi, we present the complementary perspective of WDF as promoters of soil fertility through improved Ca availability [3]. The bulk of the large amount of Ca contained in trees [4] links structural components of the apoplast, the network of cell walls and open lumina that conduct sap and contain the symplast. The apoplast and its degradation products sequester carbon for decades, centuries, and millennia, and in the case of coal, for millions of years. After N, Ca is the most important essential mineral for plant disease management [5]. Additionally, $\mathrm{Ca}$ regulates acidity and the formation of protective layers in wood and bark [6], signals changes in biological functions, and enhances water and nutrient translocation [7].

In northern New England forests, the primary rooting zone for essential element uptake is the organic-enriched forest floor. In these naturally acidic soils, podzolization depletes Ca from the rooting zone [8]. Depletion is accelerated by deposition of acidic oxides of sulfur (S) and N pollutants [9]. In the soil solution, the $\mathrm{S}$ and $\mathrm{N}$ oxides are strongly acidic anions which mobilize and leach essential base cations (e.g., $\mathrm{Ca}, \mathrm{Mg}$, and $\mathrm{K}$ ) out of the forest floor. Acid deposition also mobilizes potentially harmful aluminum (Al), from an essentially inexhaustible supply in underlying mineral soil and parent material. Mobilized Al tends to displace essential Ca from ion exchange sites in soil organic matter [10] and fine root tips [11]. Following root uptake, Al is largely precipitated out of solution due to the decreased acidity in the fine root cortex [11], resulting in very low concentrations of Al in wood. Calcium depletion and Al mobilization have caused growth declines and increased mortality in spruce [10,12-14] and maple [15-19].

Breakage and tree mortality attributable to normal stand development or to disturbance events adds large amounts of Ca-rich wood to the WDF communities associated with the naturally base-poor and depleted forest floor. Microcosm tests demonstrated movement of Ca during wood decay of both conifers [20,21] and hardwoods [22]. Long-term field studies were established in New Hampshire at the Bartlett Experimental Forest (BEF) in 1995 and in Maine at the Penobscot Experimental Forest (PEF) in 1996 and 1997 to investigate the role of the decay process in the cycling of calcium and other essential bases [23]. Study results over the first 12 years have been published [3,24].

The objectives of this research are to: (1) determine the relationship of amount of decay (density loss) to base element concentration during 12 years of ground contact; (2) compare concentrations of $\mathrm{Ca}, \mathrm{Mg}$, and $\mathrm{Al}$ in decaying wood and adjacent forest floor after 10 and 20 years of decay; and (3) determine the relationship of $\mathrm{Ca}$ concentration and cation exchange capacity of adjoining soil after 19 years of ground contact. 


\section{Methods}

Field site characteristics and methods for measurement at the Penobscot Experimental Forest in Maine (PEF, 44 $49^{\prime} 54^{\prime \prime} \mathrm{N}, 68^{\circ} 35^{\prime} 51^{\prime \prime} \mathrm{W}$ ) and the Bartlett Experimental Forest in New Hampshire

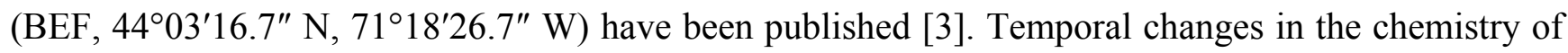
decaying wood was determined for red spruce (Picea rubens Sarg.) and red maple (Acer rubrum L.) at PEF and BEF and for eastern hemlock (Tsuga canadensis (L.) Carr.) and paper birch (Betula papyrifera Marsh.) at PEF. For each combination of location and species, 20 dominant or co-dominant trees, $15-45 \mathrm{~cm}$ diameter at $1.3 \mathrm{~m}$ above ground were selected and felled. At harvest, reference disks (5-cm thick) were cut from all felled stems at $3 \mathrm{~m}$ and $7 \mathrm{~m}$ above the stumps. Small soil pits were dug next to the intervening 4-m bolt, and samples of O-horizon soil were collected. Decaying wood from the 4-m bolt was taken at two-year sampling intervals for the next 12 years. At each sampling, a 10-cm thick "cleaning" disk from the exposed lower end was cut and discarded and a freshly sawn 5-cm thick sample disk was taken for chemical analysis.

Wood sample disks (5-cm thick) were air-dried at room temperature and oven-dried at $90{ }^{\circ} \mathrm{C}$ for $48 \mathrm{~h}$. Blocks of sapwood located $90^{\circ}$ from the point of ground contact were split from sample disks. The dimensions of the blocks were measured and calculated for samples collected after up to eight years of ground contact and weighed. Density $\left(\mathrm{g} \cdot \mathrm{cm}^{-3}\right)$ was calculated as the mass to volume ratio.

Blocks were milled into powder to pass a 1-mm mesh. After 10 or more years of ground contact, the sample bolts were too heavily degraded to permit volume measurements and friable decayed wood was milled as above. Milled wood powder was ashed and dissolved in $\mathrm{HCl}$. Concentrations of $\mathrm{Ca}, \mathrm{Mg}, \mathrm{K}$ in ash solutions were determined by inductively coupled plasma optical emission spectroscopy (ICP-OES).

Forest floor soil samples adjacent to the felled stems were taken at the time of harvest and at 10 years after harvest and analyzed at the certified analytical laboratory at the University of Maine, Orono. The same protocol was applied to 10-year and 12-year decayed wood residues. In addition to decayed spruce wood at PEF and BEF, decayed spruce wood in ground contact for 19 and 24 years was available from earlier studies at Howland and Kossuth, Maine and analyzed by the same standard protocols [3]. Exchangeable Ca of decayed and sound wood at Howland and Kossuth were determined by inductively coupled plasma-atomic emission spectroscopy (ICP-AES) of freeze-thaw extracts in $10 \mathrm{mM} \mathrm{HCl}$. Cation exchange capacity was determined for the Howland and Kossuth samples [3]. Soil data from the same general area as the decaying wood at Howland and Kossuth were available from research conducted by the US Geological Survey Laboratory, Troy, NY, USA.

Temporal changes in wood density and for concentrations of $\mathrm{Ca}, \mathrm{K}$, and $\mathrm{Mg}$ were tested for statistical significance using a graphical approach (application of Rule 7 in [25]). In this technique, the difference between the value at each time interval and time zero was obtained. The mean and 95\% confidence interval (CI) of those differences was then calculated. When the $95 \%$ CI did not include zero, the mean values were significantly different $(p<0.05)$. Mean differences in concentrations of exchangeable $\mathrm{Ca}, \mathrm{Mg}$, and $\mathrm{Al}$ between decayed wood and the forest floor and exchangeable $\mathrm{Ca}$ and cation exchange capacity were determined using the overlap rule for 95\% CI (application of Rule 6 in [25]). 


\section{Results}

Loss in mass per unit volume (mean change in sapwood density) over the first eight years in ground contact varied among tree species and site (Figure 1). The first significant loss of mass in spruce occurred after four years at BEF with a maximum loss of $15 \%$ after eight years. The same pattern for spruce was observed at PEF with a maximum of $18 \%$ after eight years; whereas, mass loss in hemlock at PEF began after two years with a maximum of $22 \%$ after eight years. Significant loss of mass in maple at BEF and PEF was $6 \%$ and $16 \%$, respectively, after two years and $33 \%$ and $67 \%$, respectively, after eight years. Significant loss of mass in birch at PEF was $25 \%$ after two years and $38 \%$ after eight years.
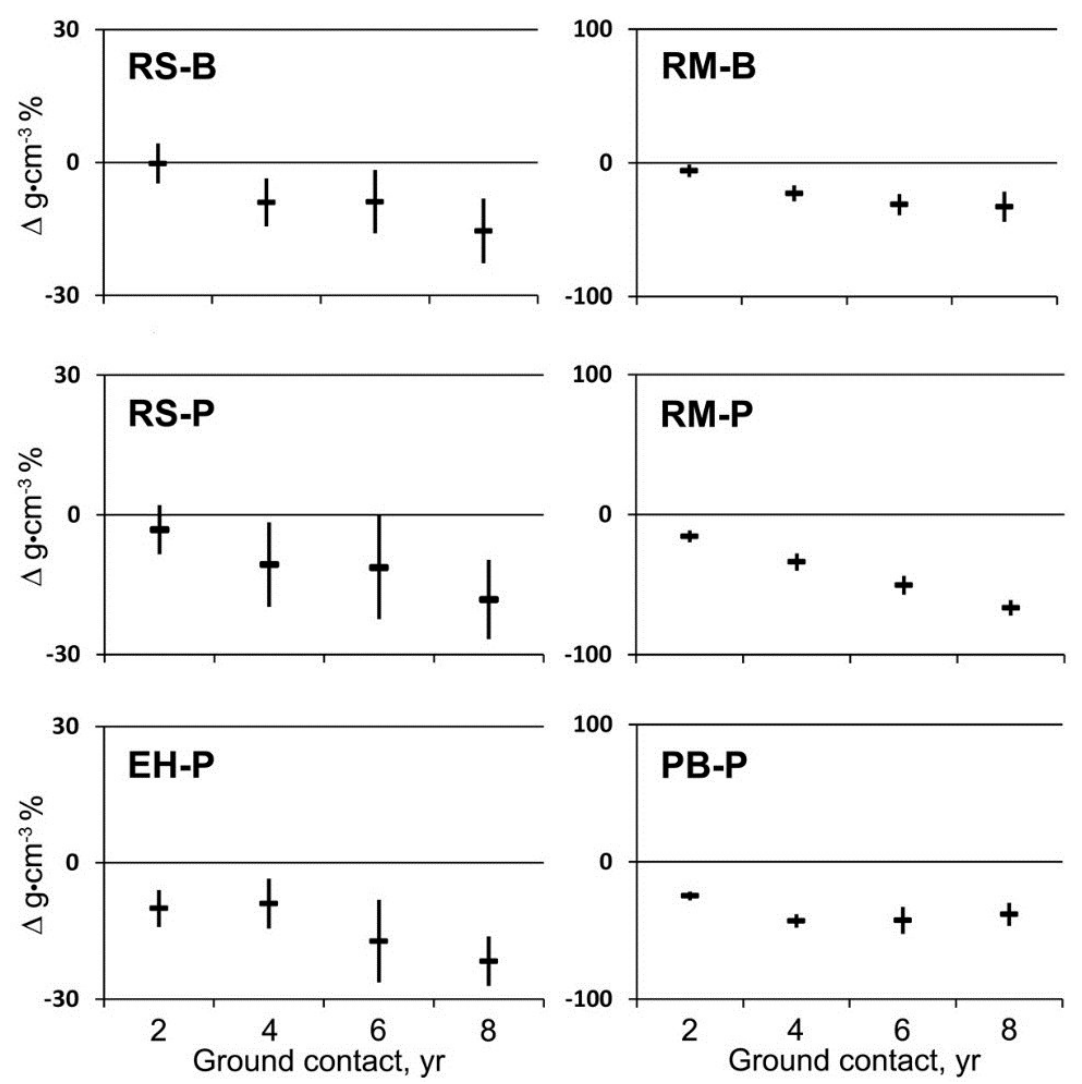

Figure 1. Mean change in wood density and 95\% confidence interval $(n=20)$ for red spruce (RS), eastern hemlock (EH), red maple (RM), and paper birch (PB) at the Bartlett Experimental Forest (B) or the Penobscot Experimental Forest (P) during two to eight years of decay with ground contact.

Decayed wood with a density below $0.1-0.2 \mathrm{~g} \cdot \mathrm{cm}^{-3}$ readily fragmented and no longer allowed for accurate volume measurements, so density measurements were discontinued after eight years. Based on visual appearance, decay of coniferous wood (spruce and hemlock) appeared to be brown-rot whereas decay of broadleaved species (maple and birch) appeared to be white-rot. Brown-rotted wood readily fragmented at lower mass losses than wood decayed by white-rot fungi. Although no floristic analysis was attempted, corticioid and stereaceous fungi were frequently found on the decaying logs as well as various gilled and poroid forms on both the wood and adjacent soil. 
During 12 years of ground contact, concentration trends for the essential base cations $\mathrm{Ca}, \mathrm{K}$, and $\mathrm{Mg}$ followed three distinct patterns (Figure 2). Ca, the most abundant base cation in sapwood, had an initial mean concentration of $17-19 \mathrm{mmol} \cdot \mathrm{kg}^{-1}$ in spruce and hemlock and 14-16 in maple and birch, and it steadily increased over the first eight years. $\mathrm{K}$, the second most abundant base cation in sapwood, had an initial mean concentration or 6-9 $\mathrm{mmol} \cdot \mathrm{kg}^{-1}$ in spruce and hemlock and $8-13$ in maple and birch and initially increased for two years, but was highly variable with a decreasing trend in concentration over time. The mean concentration of $\mathrm{Mg}$ varied comparatively little from the initial 3-4 mmol $\cdot \mathrm{kg}^{-1}$ in spruce and hemlock and 4-5 in maple and birch.
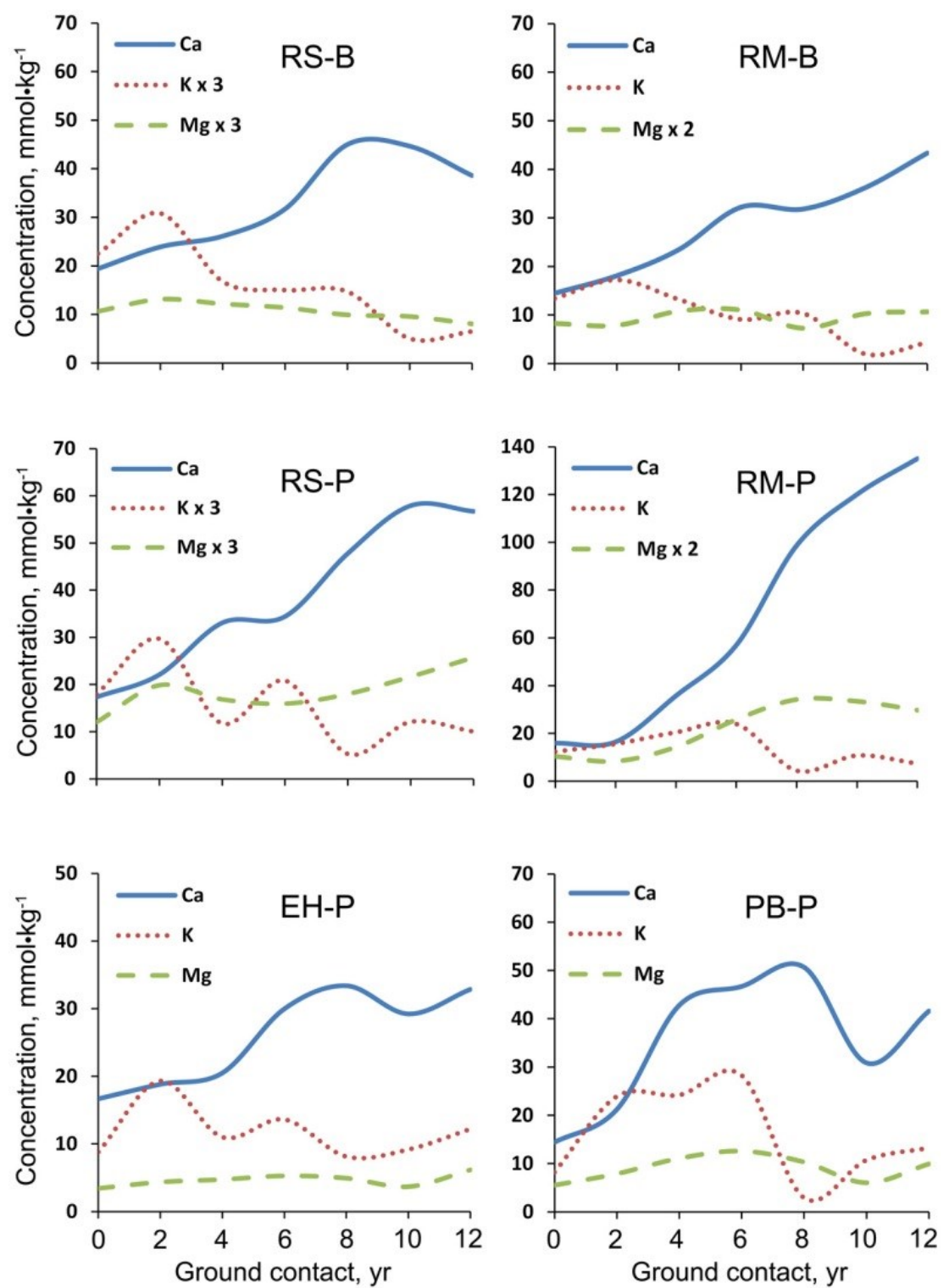

Figure 2. Pattern of mean concentration $(n=20)$ of $\mathrm{Ca}, \mathrm{K}, \mathrm{Mg}$ for red spruce $(\mathrm{RS})$, eastern hemlock (EH), red maple (RM), and paper birch (PB) at the Bartlett Experimental Forest (B) or the Penobscot Experimental Forest (P) during two to 12 years of decay in ground contact.

Calcium (Ca) concentrations progressively increased over the first eight years of ground contact and appeared to be sustained thereafter (Figures 2 and 3). After two years, Ca concentrations had not changed significantly or experienced small increases per unit mass and generally no change per unit 
volume with one small increase in maple at BEF (Figure 3). After eight years, Ca concentration increased significantly per unit mass and volume relative to the initial $\mathrm{Ca}$ concentration in all cases (Figure 3). The overall increase in $\mathrm{Ca}$ concentration after eight years relative to the initial concentration was $218 \%$ per unit mass and $79 \%$ per unit volume. Comparable values for Ca were observed in decayed wood samples after 10 and 12 years, but fragmenting decayed wood could no longer yield reliable estimates of volume, and increasing evidence of animal activity caused the removal of the most decayed portion of the logs. This loss of decayed wood in the more advanced stages of decay biased our sampling to the less degraded portions of the decaying log. This effect was most obvious in birch in which Ca concentrations of wood appeared more like wood decayed for less time with soil contact. Therefore, after 10 years decaying with ground contact, the humus of the lower forest floor became the reference point for concentrations per unit mass for the fragmenting wood in advanced stages of decay.

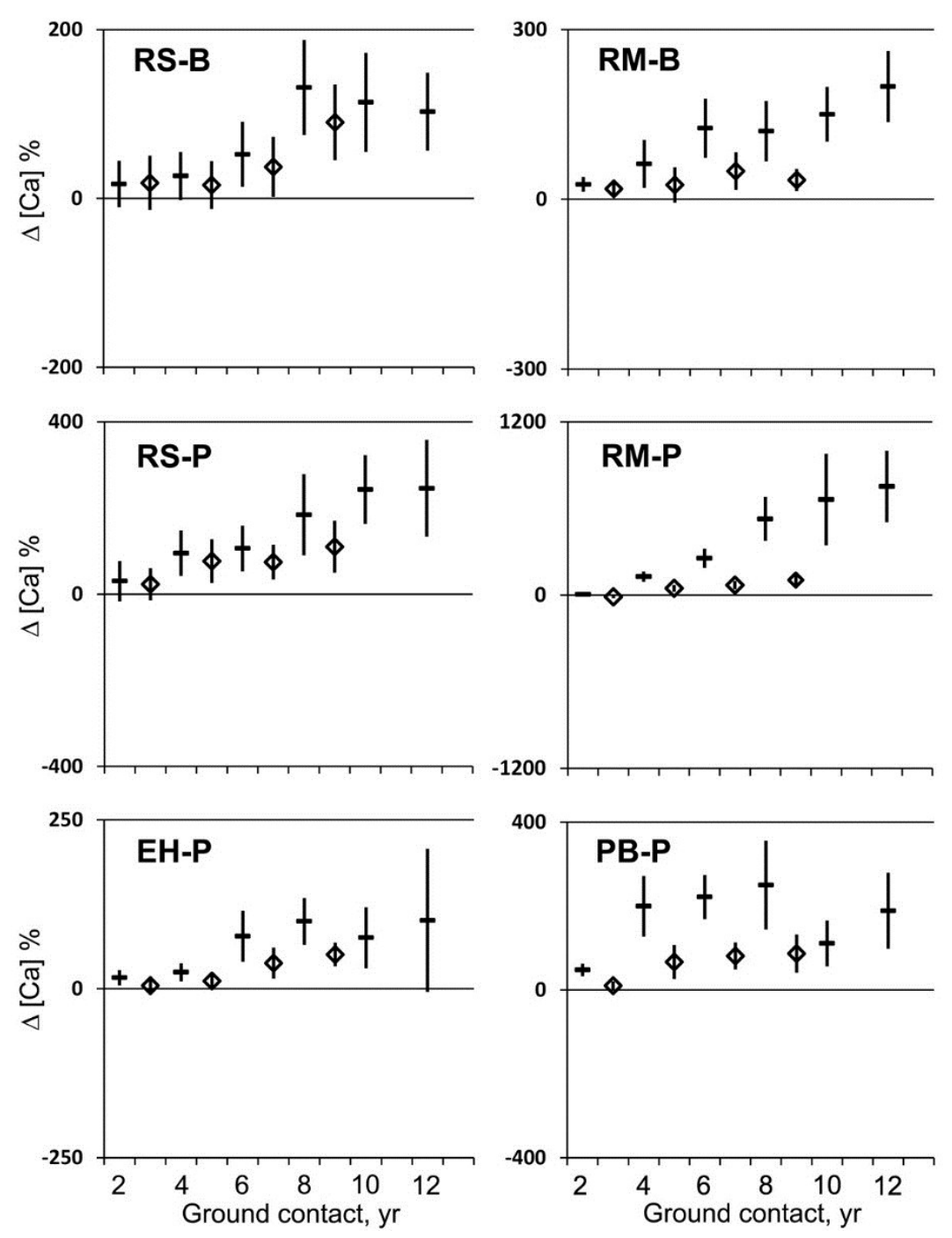

Figure 3. Mean change in calcium concentration per unit mass (dash) and per unit volume (diamond) and $95 \%$ confidence interval $(n=20)$ for red spruce $(\mathrm{RS})$, eastern hemlock $(\mathrm{EH})$, red maple $(\mathrm{RM})$, and paper birch $(\mathrm{PB})$ at the Bartlett Experimental Forest $(\mathrm{B})$ or the Penobscot Experimental Forest $(\mathrm{P})$ during two to 12 years of decay with ground contact. 
After two years of ground contact, potassium $(\mathrm{K})$ concentrations of decaying sapwood increased significantly per unit mass in all cases and per unit volume, except in maple at PEF (Figure 4). The overall increase in $\mathrm{K}$ concentration after two years was $91 \%$ per unit mass and $66 \%$ per unit volume. This initial increase was not sustained and $\mathrm{K}$ concentrations were highly variable, but generally decreased as decay progressed (Figure 4). After eight years, K concentration decreased significantly per unit mass relative to the initial concentration, except in hemlock and maple at BEF, and per unit volume in all cases except hemlock. The overall decrease in K concentration after eight years was $35 \%$ per unit mass and 53\% per unit volume. After 10 and 12 years, $\mathrm{K}$ concentrations per unit mass were less than or equal to initial sapwood concentrations.
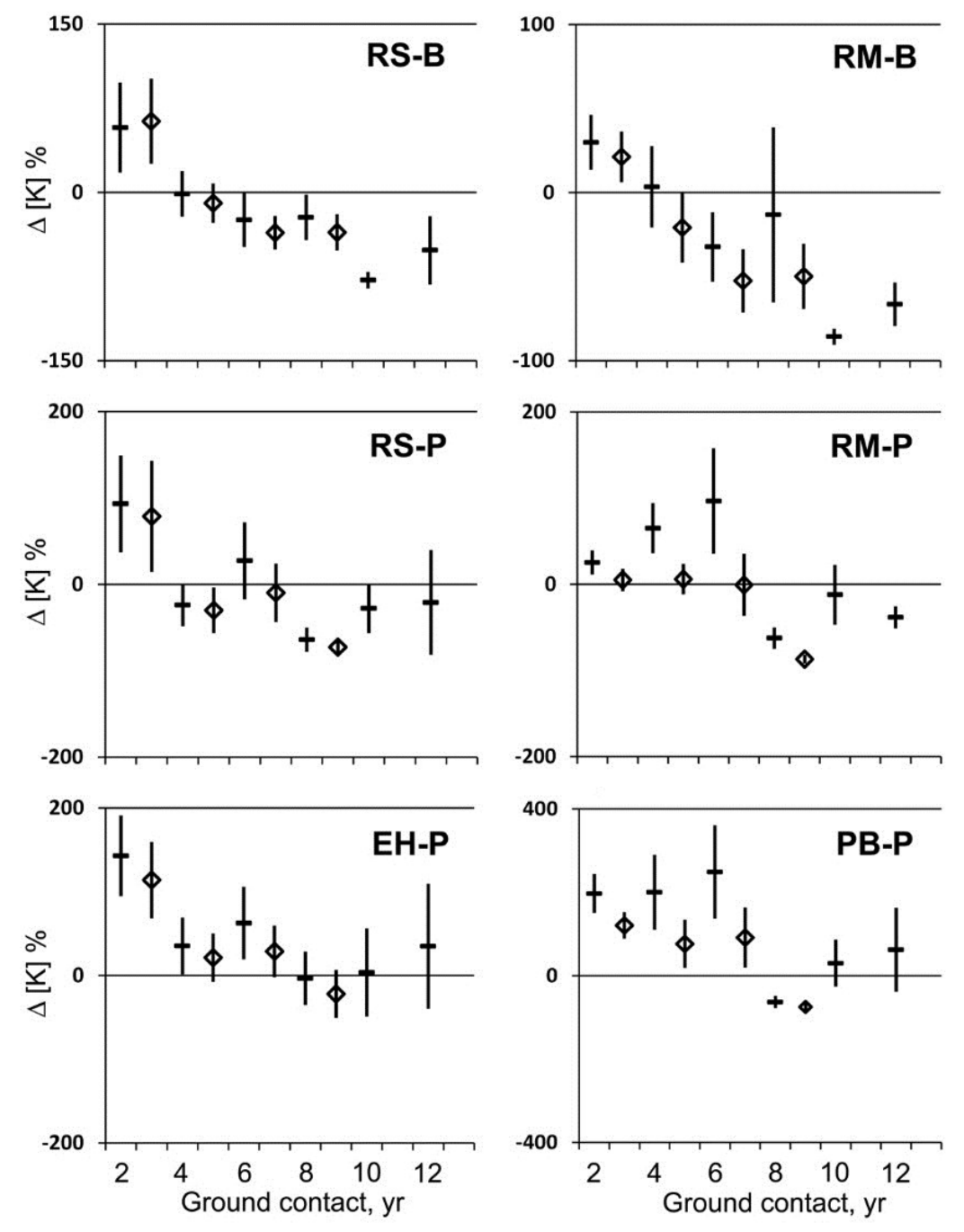

Figure 4. Mean change in potassium concentration per unit mass (dash) and per unit volume (diamond) and 95\% confidence interval $(n=20)$ for red spruce $(\mathrm{RS})$, eastern hemlock $(\mathrm{EH})$, red maple (RM), and paper birch (PB) at the Bartlett Experimental Forest (B) or the Penobscot Experimental Forest (P) during two to 12 years of decay with ground contact.

Magnesium $(\mathrm{Mg})$ concentrations were variable over time but tended not to vary substantially from initial sapwood concentrations (Figures 2 and 5). After two years, Mg concentration per unit mass increased significantly in three cases, decreased significantly in one case, and did not change significantly in two cases (Figure 5). Overall, Mg concentration increased $26 \%$ on a mass basis, but 
with no significant change on a volume basis. After eight years, the mean change in $\mathrm{Mg}$ concentration per unit mass increased in three cases and did not change significantly in three cases relative to the initial $\mathrm{Mg}$ concentration with an overall increase of 58\% (mostly attributed to a large increase in maple at PEF) per unit mass, but no significant change on a volume basis. After 10 and 12 years, half the samples of decayed wood had increased $\mathrm{Mg}$ concentration per unit mass relative to the initial sapwood concentration, half did not, and none experienced a significant decrease. Due to wood deterioration, molar concentrations of essential base cations could no longer be expressed on a volume basis after 10 and 12 years of ground contact. For these samples of decayed wood, concentrations of exchangeable $\mathrm{Ca}$ and $\mathrm{Mg}$ were compared to the forest floor (Figure 6). Exchangeable Ca concentrations of decayed wood (R) of spruce (S) and maple (M) at 10 years and the forest floor (F) at 0 years did not differ significantly as indicated by overlapping 95\% confidence intervals (Figure 6), but decayed wood of birch (B) had a significantly lower concentration as indicated by no overlap of confidence intervals (Figure 6).
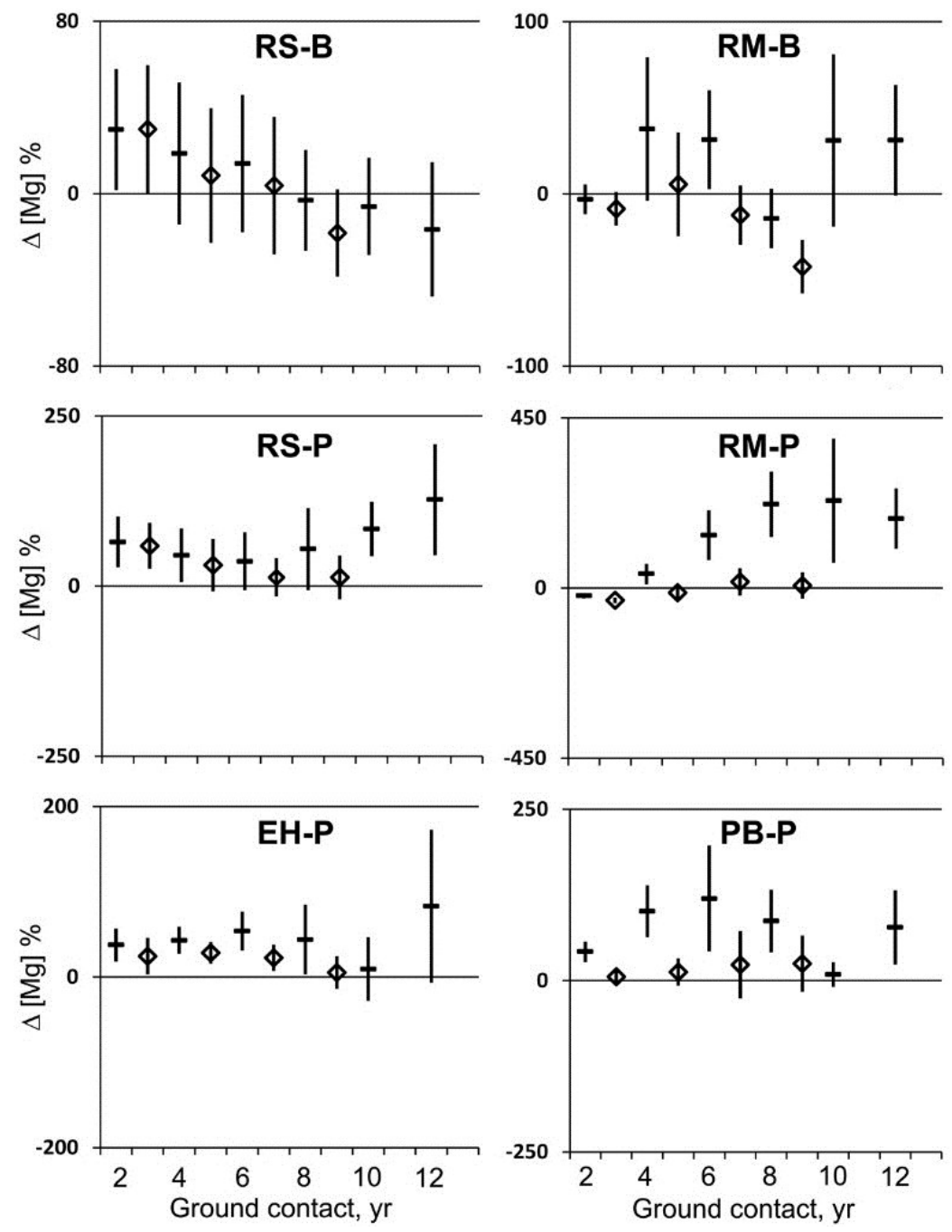

Figure 5. Mean change in magnesium concentration per unit mass (dash) and per unit volume (diamond) and 95\% confidence interval $(n=20)$ for red spruce $(\mathrm{RS})$, eastern hemlock $(\mathrm{EH})$, red maple (RM), and paper birch (PB) at the Bartlett Experimental Forest (B) or the Penobscot Experimental Forest (P) during two to 12 years of decay with ground contact. 

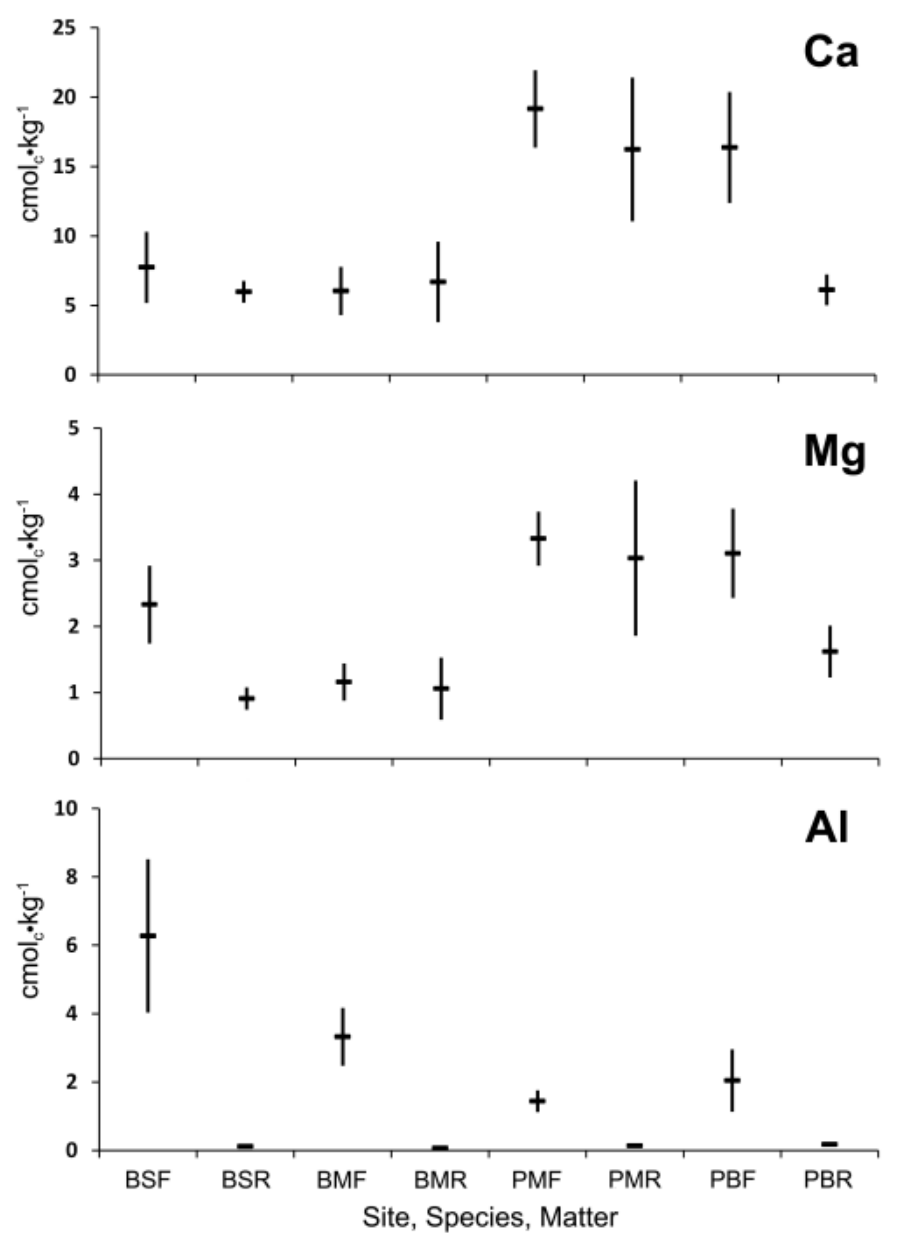

Figure 6. Comparison of mean concentration of exchangeable $\mathrm{Ca}, \mathrm{Mg}$, and $\mathrm{Al}$ and $95 \%$ confidence interval $(n=20)$ for the lower forest floor $(\mathrm{F})$ and decayed wood $(\mathrm{R})$ or red spruce (S), red maple (M), and paper birch (B) at the Bartlett Experimental Forest (B) or the Penobscot Experimental Forest (P) after 10 years of decay with ground contact.

Exchangeable $\mathrm{Mg}$ concentrations of decayed wood of maple at both BEF and PEF did not differ significantly from the forest floor, but decayed wood of spruce and birch had a significantly lower $\mathrm{Mg}$ concentration. Exchangeable Al concentrations of decayed wood was significantly and substantially less than the forest floor in all cases. There was no significant difference in exchangeable $\mathrm{Ca}, \mathrm{Mg}$, and $\mathrm{Al}$ of forest floor samples taken at 0 and 10 years or between decayed wood samples at 10 and 12 years.

Exchangeable Ca concentrations of decayed spruce wood after 19 years of decay in ground contact at Howland and Kossuth, Maine, and after 24 years at Kossuth, did not differ significantly from the forest floor (Figure 7) as in the case of 10 and 12 years of decay at BEF and PEF (Figure 6). Exchangeable $\mathrm{Mg}$ and $\mathrm{Al}$ concentrations of decayed wood were significantly lower than those of the forest floor as at BEF and PEF.

After 19 years of decay with ground contact, decayed wood residue of spruce at Howland and Kossuth had a significant five to six-fold increase in exchangeable $\mathrm{Ca}$ and a four-fold increase in cation binding capacity (Figure 8). The concentrations for $\mathrm{Ca}$ in Figure 8 are greater than in Figure 7 due to differences in the method of base cation extraction. Freeze-thawing in $10 \mathrm{mM} \mathrm{HCl}$ (Figure 8) mobilizes $20 \%-25 \%$ more $\mathrm{Ca}$ than $30 \mathrm{~min}$ exposure to $1 \mathrm{M}$ ammonium chloride (Figure 7) due to the greater activity of the dilute acid than the neutral salt. 

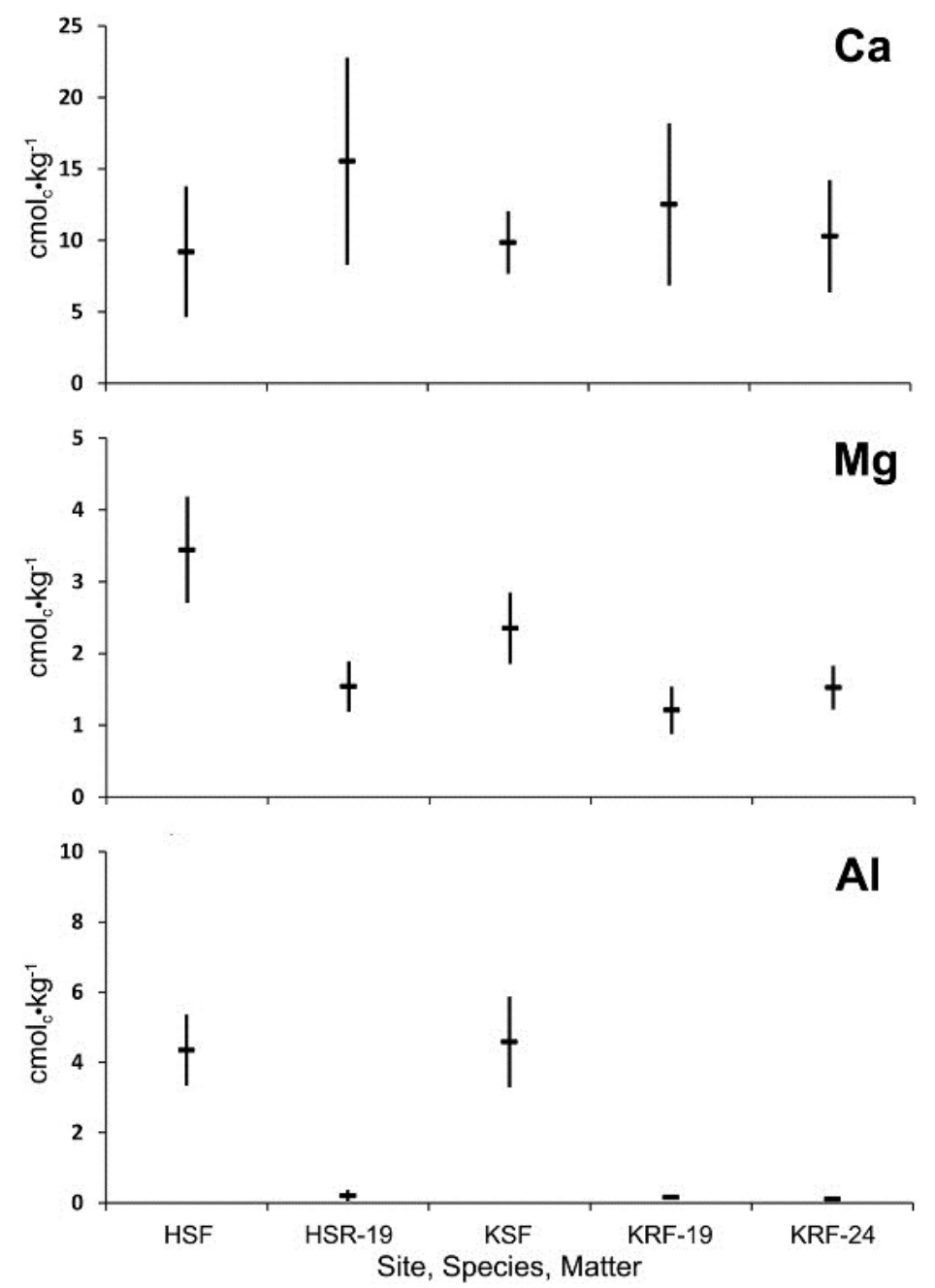

Figure 7. Comparison of mean concentration of exchangeable $\mathrm{Ca}, \mathrm{Mg}$, and $\mathrm{Al}$ and $95 \%$ confidence interval ( $n=10$ forest floor; $n=5$ decayed wood) for the lower forest floor (F) at Howland, ME (H), and Kossuth, ME (K), and decayed wood (R) of red spruce after 19 and 24 years of decay with ground contact.
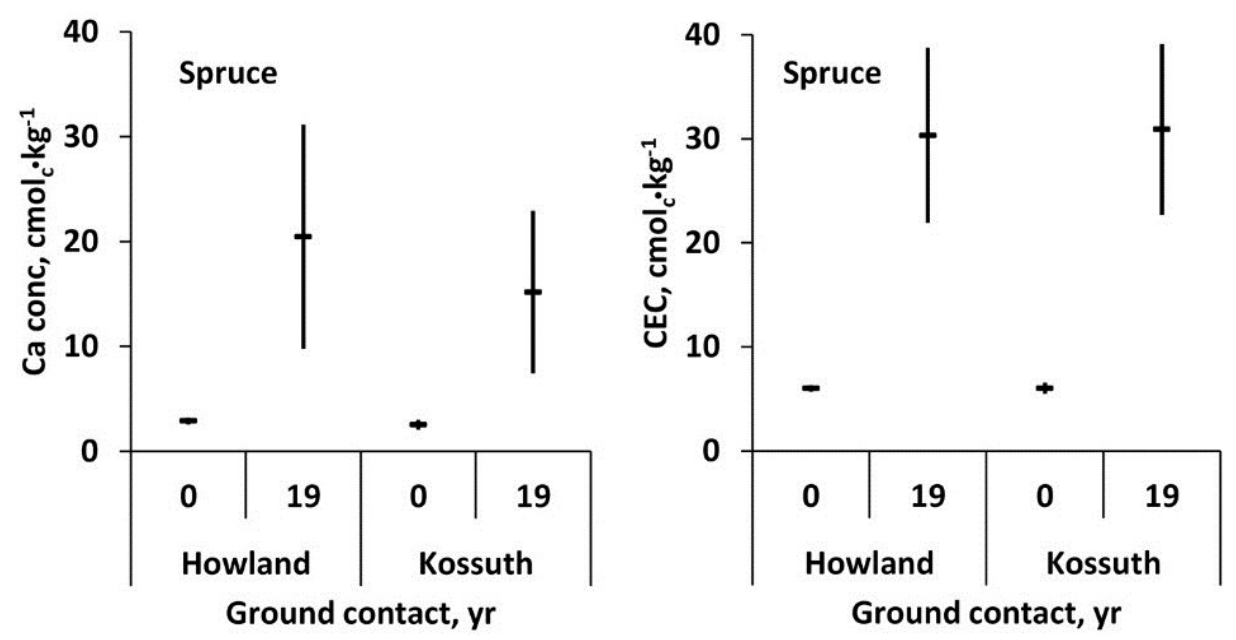

Figure 8. Mean exchangeable $\mathrm{Ca}$ concentration and mean cation exchange capacity (CEC) and $95 \%$ confidence interval $(n=5)$ of red spruce sapwood at time of felling ( 0 years) and after 19 years of decay with ground contact at Howland, ME and Kossuth, ME [3]. 
Decayed stem sections of all species were penetrated with fine absorbing roots and mycelial cords (Figure 9). The same colonization by roots and mycelia chords was observed in decayed wood of all sizes, including shed branches and dead roots. Feeder roots of trees were abundant throughout the forest floor and less so in the underlying mineral soil.

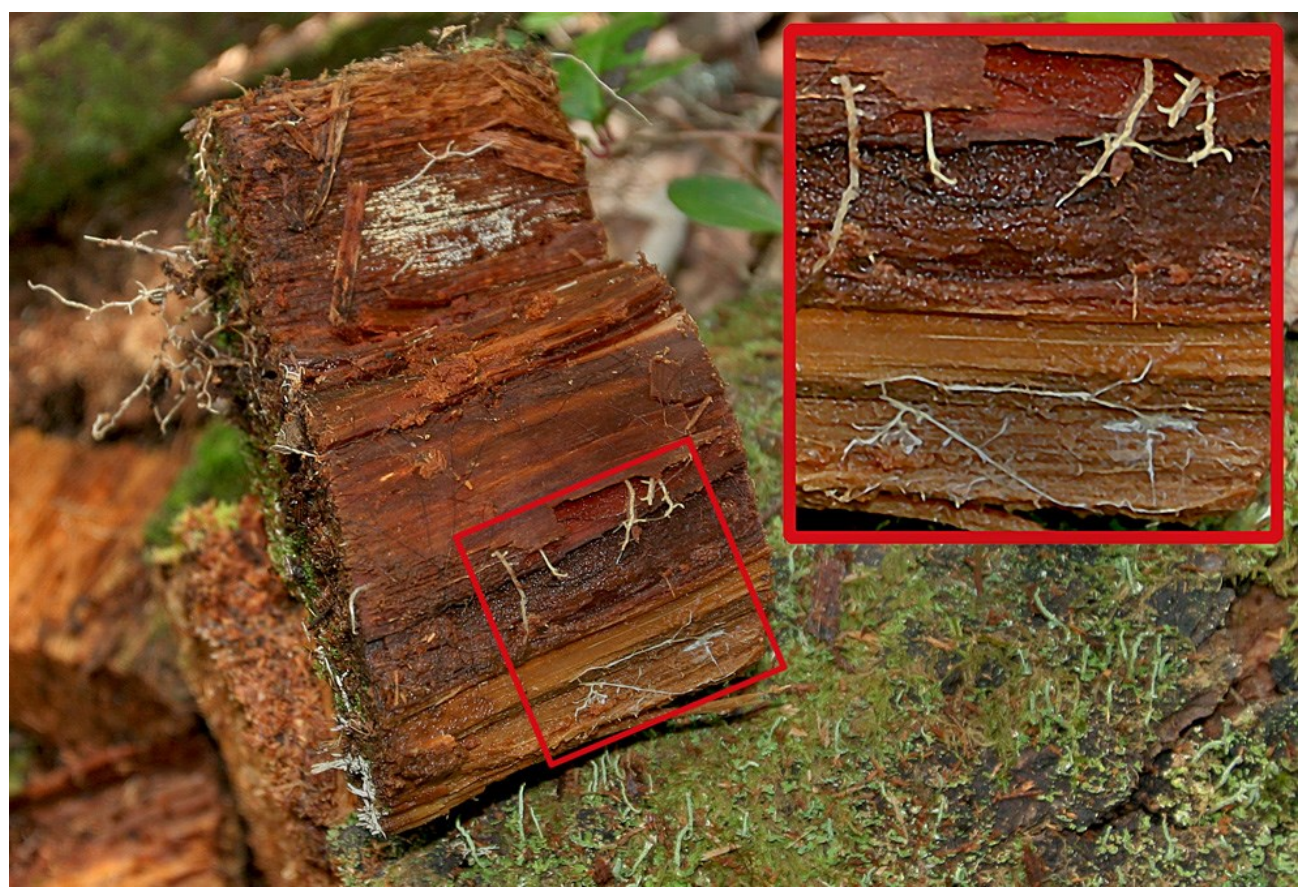

Figure 9. Decayed spruce stem section penetrated by fine roots, mycelium, and mycelial cords (insert) after 12 years of decay with ground contact.

\section{Discussion}

The current report expands on the earlier reports by Shortle et al. [3] and Smith et al. [24]. Mass loss of sapwood on a volume basis was variable with a $50 \%$ loss reached for some logs in six to eight years for conifers and four to six years in hardwoods, while other logs remained essentially sound over the same period. The potential effect of heartwood extractives on decay rate was determined by analysis of sapwood only. The variation in decay rate was consistent with laboratory decay tests using various species of fungi. Spruce wood decayed by nine different wood-decay fungi for eight months in vitro had a range of mass loss of $2 \%-69 \%$ with an average of $28 \% \pm 20 \%$ [20]; southern beech wood decayed by 12 different wood-decay fungi for four months had a range of mass loss of 0-90\% with an average of $35 \% \pm 22 \%$ [22]. Variation due to environmental conditions was likely to make a minor contribution to variation in decay rates once the wood-decay fungi and associated microorganisms colonized the wood. For example, wide differences in initial moisture content had no effect on the rate of decay of spruce (conifer) and sweetgum (hardwood) sapwood under laboratory conditions [26]. Therefore, most of the variation observed is apparently due to the variation in the species of decay fungi, as supported by the variety of fruiting bodies observed on the decaying stem sections during this study.

During the first eight years of ground contact when decaying wood passed from the early stage (mass loss less than 15\%) at two years to the advanced stage (mass loss up to 50\% or more) at eight 
years, concentrations of essential base cations, $\mathrm{Ca}, \mathrm{K}$, and $\mathrm{Mg}$, were compared using the initial sound state as a point of reference. After eight years, as the wood in an advanced stage of decay became fragmented, the reference point was changed from the initial sound wood to the forest floor into which the fragments of decayed wood were incorporated. These comparisons of exchangeable $\mathrm{Ca}, \mathrm{Mg}$, and Al between the fragmenting decayed wood and the forest floor indicated the potential for forest floor enrichment of $\mathrm{Ca}$ within the first few decades after tree death and decay.

During the early stage of wood decay after two years of ground contact, $\mathrm{K}$ enrichment occurred relative to the initial concentration in sapwood (Figure 4). After this initial gain, K concentration fluctuated prior to a net loss in the advanced stage of decay after eight years (Figure 4). During the initial stage of decay, wood became ionized and the concentration of $\mathrm{K}^{+}$ions increased rapidly, decreasing electrical resistance [27,28]. After this initial increase, the fluctuating pattern of concentration levels was consistent with the activity of cord-forming, wood-decaying fungi that have been shown to move $\mathrm{K}$ - a highly mobile, essential base cation-in and out of decaying wood along with essential elements $\mathrm{N}$ and $\mathrm{P}[2,29,30]$.

Magnesium enrichment occurred along with $\mathrm{K}$ enrichment in three of six cases during the early phase of wood decay after two years of ground contact, but in the other three cases, $\mathrm{Mg}$ remained unchanged or lost (Figure 5). This pattern of gains and losses for $\mathrm{Mg}$ continued into the advanced stage of decay after eight years, and was expected as large chord-forming wood-decaying fungi moved $\mathrm{Mg}$ in and out of decayed wood along with $\mathrm{N}, \mathrm{P}$, and $\mathrm{K}$.

Calcium enrichment progressed from early decay after two years to advanced decay after eight years of ground contact, on average nearly a doubling of the initial concentration per unit volume (Figure 3). Similar enrichment was noted for northern hardwoods at another location in New Hampshire [31]. This enrichment appeared to be sustained beyond eight years except in birch (Figure 3). However, what appears to be a loss in $\mathrm{Ca}$ in advanced decay of birch was most likely a loss from fragmentation of severely decayed wood, possibly aggravated by wood-inhabiting arthropods and their predators, leaving less-decayed wood available for sampling. The wood fragments or their digestion products then become incorporated into the forest floor.

The exchangeable $\mathrm{Ca}$ of decayed wood residue of spruce and maple after 10 and 12 years of ground contact was equivalent to that of the forest floor (Figure 6) as was spruce after 19 and 24 years (Figure 6). The lower concentration in birch after 10 and 12 years (Figure 6) is attributed to the removal of some of the advanced decayed wood by animal activity. Exchangeable $\mathrm{Mg}$ of decayed wood was less than the forest floor in spruce, but equivalent in maple. As in the earlier stages of decay, $\mathrm{Mg}$ has greater mobility than $\mathrm{Ca}$ in soils. Exchangeable Al is much lower in decayed wood than in the forest floor which overlies the mineral soil from which Al can be mobilized by increased acidity $[10,14]$.

Decayed spruce wood after 19 years of soil contact increased five to six-fold in ionically bound $\mathrm{Ca}$ and four-fold in cation binding capacity, indicating that the $\mathrm{Ca}$ was stored both in an exchangeable form and as salts, such as calcium oxalate, with varying degrees of solubility (Figure 8). The oxyanions of decayed wood that can bind divalent cations such as $\mathrm{Ca}^{2+}$ are most likely the carboxyls of oxidized side chains of lignin [32].

This ionically bound $\mathrm{Ca}$ became available for absorption by fine roots and mycorrhizae even before fragmentation incorporated the residue into the forest floor as seen by feeder roots and mycelial cords penetrating wood in an advanced stage of decay (Figure 9). The mycelial cords observed may be from 
wood decay fungi moving essential elements in and out of the decaying wood, or from mycorrhizal fungi bringing mineral nutrients accumulated in decaying wood to trees for their growth and development. The wood decay basidiomycete Hypholoma lateritium can extend vertically across soil profiles and move essential elements from the mineral soil up into the forest floor [33].

Some of the controversy about the importance of decaying boles and forest nutrition stems from the fact that the forest floor and coarse woody debris are seen as two different things, rather than different stages of the same thing. Finding the mass of fine roots in the forest floor seven times greater than decay class IV decayed wood and 10 times greater than decay class III was taken as an indication of the low importance of decaying boles in northern hardwood forests [34]. However, our study indicates that decayed wood after a decade of soil contact when analyzed by the same standard procedures as forest floor samples already has equivalent concentration of $\mathrm{Ca}$ and, in some cases, $\mathrm{Mg}$, with the major difference being how fragmented the decayed material has become for greater root penetration.

Decayed sapwood attained exchangeable calcium concentration equivalent to the forest floor after about a decade of ground contact (Figures 3 and 6). Unlike the forest floor in direct contact with the underlying mineral soil, the wood of boles in advanced stages of decay are much lower in $\mathrm{Al}$ concentration. This decayed wood enriched in exchangeable $\mathrm{Ca}$ and having a low $\mathrm{Al} / \mathrm{Ca}$ ratio $(<1)$ can become available to feeder roots of forest trees as the decayed wood becomes fragmented and added to the rooting zone over several decades. A net reduction in $\mathrm{Al} / \mathrm{Ca}$ of the root-zone can reduce stress induced by $\mathrm{Ca}$ depletion and $\mathrm{Al}$ mobilization associated with acid deposition on northern forest soils $[10,13]$. Although heartwood was not included in the analysis, we expect that heartwood would show similar patterns but at lower initial rates depending on initial base cation concentrations and wood-preserving organic compounds.

The absolute requirement of $\mathrm{Ca}$ for wood structure means that $\mathrm{C}$ sequestration depends on root-available Ca. Calcium cross-links the strands of polygalacturonic acid in pectin to form the middle lamella onto which layers of cellulose, hemicellulose, and lignin are laid down in various proportions [35]. Although lignin is dispersed throughout the layers of wood cell walls, it is the initial layer of Ca-pectate that is the most heavily lignified, protecting this layer from enzymatic degradation by plant pathogens. Ca has a strong influence on the structure, chemistry and physiology of wood formation [36,37]. Therefore, an adequate supply of root-available Ca is necessary and involves the activity of WDF.

\section{Conclusions}

We suggest that WDF promotes Ca availability, particularly for trees in the naturally acidic and potentially depleted forests of northern New England. This important role is in addition to the recycling of fixed $\mathrm{C}$ back into the atmosphere and the sequestration of $\mathrm{C}$ through humus formation. Carbon fixation by photosynthesis depends on EMF to obtain essential nutrients from the soil. Sequestration of carbon into new wood depends on $\mathrm{Ca}$, made available in part by WDF as old dead wood decomposes. The photosynthate from the tree crown sustains the symplast, the network of living cells from crown to roots. However, the $\mathrm{C}$ fixed by foliage and sequestered in the symplast is short-term (few years to few decades); while $\mathrm{C}$ sequestered in the lignocellulose of the apolast, the network of dead cell walls, is sequestered for decades, centuries, or millennia in live trees. As trees die and are decayed by WDF, the residues of decay form the organic matter of forest soils which act as 
cation exchangers for essential base cations such as $\mathrm{Ca}$ and which improve the water-holding capacity in the rooting zone of live trees. As the organic matter moves deeper into mineral soil, and oxygen for biodegradation and respiration becomes limiting, a portion of $\mathrm{C}$ fixed in forest trees can be sequestered for many millennia. In the distant past, the heavily lignified ancestors of modern forest trees became coal deposits until lignin-decomposing fungi limited this process [38]. The management of forests to sustain the current level of atmospheric carbon fixation and sequestration, and perhaps to enhance this process, requires a better understanding of the biological interactions of forest trees and forest fungi.

\section{Acknowledgments}

This long-term research was primarily funded through the Northern Research Station of the USDA Forest Service. We thank Kenneth R. Dudzik for technical assistance and Gregory Lawrence of the US Geological Survey for providing soil data. We thank the Bartlett and Penobscot Experimental Forests of the USDA Forest Service for access to study locations.

\section{Author Contributions}

Walter C. Shortle provided the initial conceptual basis and guided the field and laboratory research. Kevin T. Smith assisted in sample collection and provided conceptual context and linkages. Both Walter C. Shortle and Kevin T. Smith shared in writing the paper.

\section{Conflicts of Interest}

The authors declare no conflict of interest.

\section{References}

1. Leake, J.R.; Donnelly, D.P.; Boddy, L. Interactions between ecto-mycorrhizal and saprotrophic fungi. In Mycorrhizal Ecology; van der Heijden, M.G.A., Sanders, J.R., Eds.; Springer-Verlag: New York, NY, USA, 2002; pp. 345-372.

2. Boddy, L.; Watkinson, S.C. Wood decomposition, higher fungi, and their role in nutrient redistribution. Can. J. Bot. 1995, 73 (Suppl. 1), S1377-S1383.

3. Shortle, W.C.; Smith, K.T.; Jellison, J.; Schilling, J.S. Potential of decaying wood to restore root-available calcium in depleted forest soils. Can. J. For. Res. 2012, 42, 1015-1024.

4. Shortle, W.C.; Murdoch, P.S.; Smith, K.T.; Minocha, R.; Lawrence, G.B. Monitoring recovery from calcium depletion and nitrogen saturation. In The Delaware River Basin Collaborative Environmental Monitoring and Research Initiative: Foundation; Murdoch, P.S., Jenkins, J., Birdsey, R.A., Eds.; General Technical Report NRS-25; Northeastern Research Station, US Department of Agriculture, Forest Service: Newtown Square, PA, USA, 2008; pp. 52-62.

5. Rahman, M.; Punja, Z.K. Calcium and plant disease. In Mineral Nutrition and Plant Disease; Datnoff, L.E., Elmer, W.H., Huber, D.M., Eds.; APS Press: St. Paul, MN, USA, 2007; pp.79-93.

6. McLaughlin, S.B.; Wimmer, R. Calcium physiology and terrestrial ecosystem processes. New Phytol. 1999, 142, 373-417. 
7. Smith, K.T.; Shortle, W.C. Calcium amendment may increase hydraulic efficiency and forest evapotranspiration. Proc. Nat. Acad. Sci. 2013, 110, E3739.

8. Ponomareva, V.V. Theory of Podzolization; Gourevitch, A., Translator; Israel Program for Scientific Translation, TT 68-50442; National Technical Information Service: Springfield, VA, USA, 1969; p. 309.

9. Shortle, W.C.; Bondietti, E.A. Timing, magnitude, and impact of acidic deposition on sensitive forest sites. Water Air Soil Pollut. 1992, 61, 253-267.

10. Lawrence, G.B.; David, M.B.; Shortle, W.C. A new mechanism for calcium loss in forest-floor soils. Nature 1995, 378, 162-165.

11. Schröder, W.H., Bauch, J.; Endeward, R. Microbeam analysis of Ca exchange and uptake in the fine roots of spruce: Influence of $\mathrm{pH}$ and aluminum. Trees 1988, 2, 96-103.

12. Shortle, W.C.; Smith, K.T. Aluminum-induced calcium deficiency syndrome in declining red spruce. Science 1988, 240, 1017-1018.

13. Shortle, W.C.; Smith, K.T.: Minocha, R.; Lawrence, G.B.; David, M.B. Acidic deposition, cation mobilization, and biochemical indicators of stress in healthy red spruce. J. Environ. Qual. 1997, 26, 871-876.

14. Lawrence, G.B.; Lapenis, A.G.; Berggren, D.; Aparin, B.F.; Smith, K.T.; Shortle, W.C.; Bailey, S.W.; Varlyguin, D.; Babakov, B. Climate dependency of tree growth suppressed by acid deposition effects on soils in northwest Russia. Environ. Sci. Technol. 2005, 39, 2004-2010.

15. Lawrence, G.B.; David, M.B.; Shortle, W.C.; Bailey, S.W.; Lovett, G.M. Mechanisms of Base-Cation Depletion by Acid Deposition in Forest Soils of the Northeastern US; General Technical Report NRS-25; Northeastern Research Station, US Department of Agriculture, Forest Service: Newtown Square, PA, USA, 1999; pp. 75-97.

16. Johnson, A.H.; Moyer, A.; Bedison, J.E.; Richter, S.L.; Willig, S.A. Seven decades of calcium depletion in organic horizons of Adirondack forest soils. Soil Sci. Soc. Am. J. 2008, 72, 1824-1830.

17. St. Clair, S.B.; Sharpe, W.E.; Lynch, J.P. Key interactions between nutrient limitations and climatic factors in temperate forests: A synthesis of the sugar maple literature. Can. J. For. Res. 2008, 38, 401-414.

18. Zaccherio, M.T.; Finzi, A.C. Atmospheric deposition may affect northern hardwood forest composition by altering soil nutrient supply. Ecol. Appl. 2007, 17, 1929-1941.

19. Long, R.P.; Horsley, S.B.; Hallet, R.A.; Bailey, S.B. Sugar maple growth in relation to nutrition and stress in the northeastern United States. Ecol. Appl. 2009, 19, 1454-1466.

20. Ostrofsky, A.; Jellison, J.; Smith, K.T.; Shortle, W.C. Changes in cation concentrations in red spruce wood decayed by brown rot and white rot fungi. Can. J. For. Res. 1997, 27, 567-571.

21. Connolly, J.H.; Shortle, W.C.; Jellison, J. Weathering of mineral matter by a non-mychorrhizal fungus. Can. J. Bot. 1999, 77, 179-187.

22. Clinton, P.W.; Buchanan, P.K.; Wilke, J.P.; Small, S.J.; Kimberley, M.O. Decomposition of Nothofagus wood in vitro and nutrient mobilization by fungi. Can. J. For. Res. 2009, 39, 2193-2202. 
23. Shortle, W.C.; Jellison, J.; Smith, K.T.; Schilling, J.S. Studying the Role of Wood-Decaying Fungi in Calcium Cycling on the Penobscot Experimental Forest: A Progress Report; General Technical Report NRS-P-123; Northeastern Research Station, US Department of Agriculture, Forest Service: Newtown Square, PA, USA, 2014; pp. 147-150.

24. Smith, K.T.; Shortle, W.C.; Jellison, J.; Connolly, J.; Schilling, J. Concentrations of Ca and Mg in early stages of sapwood decay in red spruce, eastern hemlock, red maple, and paper birch. Can. J. For. Res. 2007, 37, 957-965.

25. Cumming, G.; Fidler, F.; Vaux, D.L. Error bars in experimental biology. J. Cell Biol. 2007, 177, 7-11.

26. Peterson, C.A.; Cowling, E.B. Influence of various initial moisture contents on decay of Sitka spruce and sweetgum sapwood by Polyporus versicolor in the soil-block test. Phytopathology 1973, 62, 235-237.

27. Shortle, W.C. Decaying Douglas-fir wood: Ionization associated with resistance to a pulsed electric current. Wood Sci 1982, 15, 29-32.

28. Shortle, W.C.; Smith, K.T. Electrical properties and rate of decay in spruce and fir wood. Phytopathology 1987, 77, 811-814.

29. Lindahl, B.; Finlay, R.; Olsson, S. Simultaneous, bidirectional translocation of ${ }^{32} \mathrm{P}$ and ${ }^{33} \mathrm{P}$ between wood blocks connected by mycelia cords of Hypholoma fasciculare. New Phytol. 2001, 150, 189-194.

30. Connolly, J.H.; Jellison, J. Two-way translocation of cations by the brown rot fungus, Gloeophyllum trabeum. Int. Biodeterior. Biodegrad. 1997, 39, 181-188.

31. Johnson, C.E.; Siccama, T.G.; Denny, E.G.; Koppers, M.M.; Vogt, D.J. In situ decomposition of northern hardwood tree boles: Decay rates and nutrient dynamics in wood and bark. Can. J. For. Res. 2014, 44, 1515-1524.

32. Filley, T.R.; Hatcher, P.G.; Shortle, W.C.; Praseuth, R.T. The application of ${ }^{13}$ C-labeled tetramethylammonium hydroxide $\left({ }^{13} \mathrm{C}-\mathrm{TMAH}\right)$ thermochemolysis to study fungal degradation of wood. Org. Geochem. 2000, 31, 181-198.

33. Thompson, T.; Thorn, R.G.; Smith, K.T. Hypholoma lateritium isolated from coarse woody debris, the forest floor, and mineral soil in a deciduous forest in New Hampshire. Botany 2012, 90 , 457-464.

34. Arthur, M.A.; Tritton, L.M.; Fahey, T.J. Dead bole mass and nutrients remaining 23 years after clear-felling of a northern hardwood forest. Can. J. For. Res. 1993, 23, 1298-1305.

35. Rowell, R.M.; Pettersen, R.; Tshabalala, M.A. Cell wall chemistry. In Handbook of Wood Chemistry and Wood Composites, 2nd ed.; Rowell, R.M., Ed.; CRC Press: Boca Raton, FL, USA, 2012; pp. 33-74.

36. Lautner, S.; Ehlting, B.; Windeisen, E.; Rennenberg, H.; Matyssek, M.; Fromm, J. Calcium nutrition has a significant influence on wood formation in poplar. New Phytol. 2007, 173, 743-752.

37. Eklund, L; Eliasson, L. Effects of calcium ion concentration on cell wall synthesis. J. Exp. Bot. 1990, 41, 863-867. 
38. Floudas, D.; Binder, M.; Riley, R.; Barry, K.; Blanchette, R.A.; Henrissat, B.; Martínez, A.T.; Otillar, R.; Spatafora, J.W.; Yadav, J.S.; et al. The Paleozoic origin of enzymatic lignin decomposition from 31 fungal genomes. Science 2012, 336, 1715-1719.

(C) 2015 by the authors; licensee MDPI, Basel, Switzerland. This article is an open access article distributed under the terms and conditions of the Creative Commons Attribution license (http://creativecommons.org/licenses/by/4.0/). 